Volume 8

Issue 4 - Cancer Screening

Article 8

10-18-2021

\title{
Patient-Centered Home Cancer Screening Attitudes During COVID-19 Pandemic
}

Christelle El Khoury

Elizabeth Haro

Martha Alves

Marie Claire O'Dwyer

Kate Meixner

Laura Crespo Albiac

J Nicoll Capizzano

Manasi Ramakrishnan

Cullen Salada

Sherri Sheinfeld Gorin

See next page for additional authors

Follow this and additional works at: https://aah.org/jpcrr

Part of the Community Health and Preventive Medicine Commons, Family Medicine Commons, Neoplasms Commons, Oncology Commons, Preventive Medicine Commons, Primary Care Commons, and the Virus Diseases Commons

\section{Recommended Citation}

El Khoury C, Haro E, Alves M, O'Dwyer MC, Meixner K, Albiac LC, Capizzano JN, Ramakrishnan M, Salada C, Sheinfeld Gorin S, Jimbo M, Sen A, Harper DM. Patient-centered home cancer screening attitudes during COVID-19 pandemic. J Patient Cent Res Rev. 2021;8:340-6. doi: 10.17294/2330-0698.1835

Published quarterly by Midwest-based health system Advocate Aurora Health and indexed in PubMed Central, the Journal of Patient-Centered Research and Reviews (JPCRR) is an open access, peer-reviewed medical journal focused on disseminating scholarly works devoted to improving patient-centered care practices, health outcomes, and the patient experience. 


\section{Patient-Centered Home Cancer Screening Attitudes During COVID-19 Pandemic}

\section{Authors}

Christelle El Khoury, Elizabeth Haro, Martha Alves, Marie Claire O'Dwyer, Kate Meixner, Laura Crespo Albiac, J Nicoll Capizzano, Manasi Ramakrishnan, Cullen Salada, Sherri Sheinfeld Gorin, Masahito Jimbo, Ananda Sen, and Diane M. Harper 


\title{
Patient-Centered Home Cancer Screening Attitudes During COVID-19 Pandemic
}

\author{
Christelle El Khoury, MD, Elizabeth Haro, MPH, Martha Alves, MPH, MSW, Marie Claire O'Dwyer, \\ $\mathrm{MPH}, \mathrm{MB}, \mathrm{BCH}, \mathrm{BAO}$, Kate Meixner, MD, Laura Crespo Albiac, MD, J. Nicoll Capizzano, MD, \\ Manasi Ramakrishnan, MBBS, Cullen Salada, MD, Sherri Sheinfeld Gorin, PhD, Masahito Jimbo, \\ MD, PhD, MPH, Ananda Sen, PhD, Diane M. Harper, MD, MPH, MS \\ Department of Family Medicine, University of Michigan, Ann Arbor, MI
}

\begin{abstract}
The COVID-19 pandemic disrupted health care delivery of cancer screenings. The primary aim of our work was to evaluate the degree to which populations were accepting of home-based screenings for colorectal cancer (CRC) and cervical cancer (ie, primary human papillomavirus [HPV] testing). Three groups of adults having distinct health burdens that may affect acceptance of home-based cancer screening were identified through outpatient electronic medical records: those having survived a COVID-19 hospitalization; those having been positive for a non-COVID-19 respiratory illness; or those having type 2 diabetes. A total of 132 respondents (58\% female) completed an online survey with hypothetical cases about their acceptance of home-based CRC or cervical cancer screening. Among women respondents, urine and vaginal screening for primary HPV testing was acceptable to $64 \%$ and $59 \%$, respectively. Among both men and women, at-home CRC screening with fecal immunochemical test or Cologuard ${ }^{\circledR}$ was acceptable to $60 \%$ of the respondents. When adjusting for education, women with a positive attitude toward home-based urine and vaginal screening were 49 times and 23 times more likely, respectively, to have a positive attitude toward CRC screening. These findings indicate that home-based cancer screens for CRC and primary HPV testing are acceptable to men and women and may allow for greater compliance with screening in the future. (J Patient Cent Res Rev. 2021;8:340-346.)
\end{abstract}

Keywords home-based cancer screening; colorectal cancer; cervical cancer; human papillomavirus; HPV screening

0 ARS-CoV-2 infections and the COVID-19 pandemic have caused global changes in health care delivery, including a significant impact on outpatient community-based primary care. Cancer screens requiring in-office procedures decreased by more than $90 \%$ for screenable cancers between March 19, 2020, and May 9, 2020, ${ }^{1,2}$ with the exception of the multitarget stool DNA test (Cologuard ${ }^{\circledR}$, Exact Sciences Corporation), for which use only decreased by $65 \%$. This suggests that home-based colorectal cancer (CRC) screening was more resilient to the effects of the pandemic and continued to be acceptable to patients.

Corresponding author: Diane M. Harper, Department of Family Medicine, University of Michigan, 1018 Fuller St., Ann Arbor, MI 48109-1213

(harperdi@med.umich.edu)
Three groups of adults having distinct health burdens could be expected to respond differently to cancer screening invitations. Restricted access to primary care during the pandemic has affected community-dwelling adults needing management of chronic diseases such as type 2 diabetes. ${ }^{3}$ Likewise, adults who have survived a hospitalization for COVID-19 continue to have health care needs while rehabilitating at home. ${ }^{4}$ Lastly, adults with respiratory symptoms who tested positive for a nonCOVID-19 coronavirus or a rhinovirus and did not require hospitalization still face similar restrictions in care access. ${ }^{5}$

For each of these groups of patients, participation in traditional in-office cancer screening has been disrupted by the pandemic. This situation may impact future uptake of home-based cancer screening methods if made available. CRC screening already has U.S. Food and Drug Administration (FDA) approval for homebased testing options like stool DNA tests. Additionally, the FDA is currently evaluating home-based cervical cancer screening methods based on primary human papillomavirus testing ${ }^{6,7}$ for approval in the United States. 
The primary aim of this study was to explore, through hypothetical cases, whether these three distinct cohorts of outpatient adults would be willing to participate in home-based screening for CRC and cervical cancer.

\section{METHODS}

The study was determined to be exempt by the University of Michigan institutional review board (HUM00182620).

\section{Survey Development}

The survey included sociodemographic questions and hypothetical scenarios about home-based cancer screening (Online Appendices A and B). The 3 scenarios involved home-based CRC screening using a stool sample, home-based cervical cancer screening using a urine sample, and home-based cervical cancer screening using a vaginal swab sample. Details of the test were not specified, and no other introductory materials about the cancers or the screening tests were provided. Responses ranged from not getting screened at all, delaying screening until the in-office procedures were available again, participating in the home-based screening but only in the case that the office screenings were not available, choosing to participate in the homebased screening regardless of whether or not the office screenings were available, and unsure.

We piloted the survey in 10 adults for understanding, sequencing order, and ease of answering. Qualtrics ${ }^{\circledR} \mathrm{XM}$ software (Qualtrics), a secure web-based application, was used to support the survey data.

\section{Population}

Responses to cancer screening scenarios for 3 groups of adults with differing health care needs were included. Adults with the chronic disease type 2 diabetes whose routine management was disrupted by the pandemic, adults who survived a COVID-19 hospitalization, and adults with an acute respiratory disease that was not COVID-19 were asked to participate. These 3 cohorts of adults were identified through the electronic medical records of a large Midwestern health system. Dates of hospitalization were defined for the first wave of COVID-19 from the beginning of 2020 through June 1, 2020. Cohort 1 included those with type 2 diabetes without respiratory symptoms from January 1, 2020, through September 1, 2020. Cohort 2 included those with a positive respiratory panel for a non-COVID-19 coronavirus (HKU1, 2229e, NL63, or OC43) or a rhinovirus without hospitalization from January 1, 2020, through September 1, 2020. Cohort 3 included those that had survived a COVID-19 hospitalization and returned home between January 1, 2020, and May 31, 2020, thus allowing survivors at least 3 months at home for recovery.
All adults were contacted by phone or email and invited to participate in the survey after September 1, 2020. We attempted contact up to 3 times and, for those agreeing, we sent 1 follow-up reminder email to complete the survey.

Table 1. Demographic Descriptors

\begin{tabular}{|c|c|}
\hline Variable & $\begin{array}{c}\text { Mean (SD) } \\
\text { or } n(\%)\end{array}$ \\
\hline Age in years, mean (SD) & $56.3(15.6)$ \\
\hline \multicolumn{2}{|l|}{ Race, n (\%) } \\
\hline White & $93(71.5 \%)$ \\
\hline Black & $25(19.2 \%)$ \\
\hline $\begin{array}{l}\text { Other (Hispanic, Asian, Alaska Native, } \\
\text { American Indian, MENA, Native } \\
\text { Hawaiian, Pacific Islander, multi-race) }\end{array}$ & $12(9.2 \%)$ \\
\hline \multicolumn{2}{|l|}{ Gender, n (\%) } \\
\hline Female & $76(57.6 \%)$ \\
\hline Male & $56(42.4 \%)$ \\
\hline \multicolumn{2}{|l|}{ Population cohort, n (\%) } \\
\hline Diabetic - chronic illness & $50(37.9 \%$ \\
\hline Acute respiratory - non-COVID-19 & $41(31.1 \%)$ \\
\hline Survived hospitalization for COVID-19 & $41(31.1 \%)$ \\
\hline \multicolumn{2}{|l|}{ Partner status, n (\%) } \\
\hline Partnered & $87(66.4 \%)$ \\
\hline Single & $44(33.6 \%)$ \\
\hline \multicolumn{2}{|l|}{ Occupation, n (\%) } \\
\hline Employed & $45(35.7 \%)$ \\
\hline Student & $3(2.4 \%)$ \\
\hline Unemployed & $20(15.9 \%)$ \\
\hline Retired/Disabled & $58(46.0 \%)$ \\
\hline \multicolumn{2}{|l|}{ Education, $\mathrm{n}(\%)$} \\
\hline High school or less & $18(13.7 \%)$ \\
\hline Some college & $42(32.1 \%)$ \\
\hline Completed college & $39(29.8 \%)$ \\
\hline Post college & $32(24.4 \%)$ \\
\hline \multicolumn{2}{|l|}{ Insurance, n (\%) } \\
\hline Private & $75(56.8 \%)$ \\
\hline $\begin{array}{l}\text { Public (Medicaid, Medicare, Tribal, other } \\
\text { state-sponsored) }\end{array}$ & $56(42.4 \%)$ \\
\hline None & $1(0.8 \%)$ \\
\hline \multicolumn{2}{|l|}{ Length of time with PCP, n (\%) } \\
\hline 3 or fewer years & $47(35.9 \%)$ \\
\hline More than 3 years & $84(64.1 \%)$ \\
\hline \multicolumn{2}{|l|}{ Number in household, n (\%) } \\
\hline 2 or fewer persons & $81(62.8 \%)$ \\
\hline More than 2 persons & $48(37.2 \%)$ \\
\hline \multicolumn{2}{|l|}{ Tobacco use, n (\%) } \\
\hline Current/Ever & $38(29.0 \%)$ \\
\hline Never & $93(71.0 \%)$ \\
\hline
\end{tabular}

MENA, Middle East and North Africa; PCP, primary care physician; $S D$, standard deviation. 


\section{Statistical Analysis}

In order to have the true proportion of acceptance of home cancer screening be estimated within \pm 8 percentage points with $95 \%$ confidence, when the true proportion of acceptance is $70 \%$, we needed a minimum of 132 respondents. Descriptive statistics produced frequencies, and logistic regression analyses were performed to test univariate predictors of home-based screening. All data were analyzed with Statistica ${ }^{\circledR}$ software (version 13, TIBCO Software Inc.).

\section{RESULTS}

Of the 879 people contacted, $132(15 \%)$ completed the survey; diabetics had the highest response rate of $27 \%$ (50 of 183), followed by those with non-COVID-19 respiratory illnesses $(16 \%, 41$ of 259$)$ and the COVID-19 hospital survivors $(9 \%, 41$ of 427$)$. On average, the diabetic group was the oldest, with mean age of 61 years (range: $23-79)$, followed by 58 years $(31-77)$ for those surviving COVID-19 hospitalization and 50 years (18-94) for those with acute non-COVID-19 respiratory illnesses. Table 1 shows that a majority of respondents were White, female, partnered, retired/disabled, living with no more than one other person, and had never smoked. Most respondents $(86.3 \%)$ had some college, complete college, or postcollege education, and more than half $(56.8 \%)$ had private insurance versus $42.4 \%$ on public plans. A majority also had a relationship with their primary care physician for more than 3 years.

Table 2 shows the range of positive and negative response categories for each home screening method. For homebased urine cervical cancer screening, $65 \%$ of women had a positive attitude, 44 percentage points above those with a negative attitude $(\mathrm{P}<0.001)$. Likewise, for home-based vaginal cervical cancer screening, $59 \%$ of women had a positive attitude, 32 percentage points above those with a negative attitude $(\mathrm{P}<0.001)$. Additionally, for homebased fecal CRC screening, $60 \%$ of men and women had a positive attitude, 37 percentage points above those with a negative attitude $(\mathrm{P}<0.001)$.

Logistic regression modeling was used to predict those with positive attitudes toward home-based cancer screening (Table 3). Univariate modeling showed no descriptive predictors of home vaginal- or urine-based cervical cancer screening, including length of time with the current primary care physician. Those with postcollege education were 6.75 times more likely to have a positive attitude toward home-based CRC screening (odds ratio [OR]: $6.75,95 \%$ CI: $1.37,32.26)$ compared to those with a high school or less education. In addition, we found that having a positive attitude toward home-based CRC screening significantly predicted those women who had positive attitudes toward home-based urine (OR: 52 [95\% CI: 8, 327]) and vaginal (OR: 25 [95\% CI: 5, 138]) cervical cancer screens, by comparison to those with negative attitudes. After adjusting for education, women with positive attitudes toward home-based urine and vaginal cervical cancer screening were more likely to screen with home-based fecal CRC screening (adjusted OR of 48.7 [95\% CI: 7, 336] and 23 [95\% CI: 4, 142], respectively).

Table 4 presents the attitudinal frequencies by age and gender for which the cancer screenings are recommended by the U.S. Preventive Services Task Force and American Cancer Society. ${ }^{8-10}$ For home-based CRC screening, 60\% of age-appropriate men and women affirmed this choice. Likewise, for home-based cervical cancer screening, $72 \%$ and $64 \%$ of age-appropriate women affirmed the urine and vaginal methods, respectively. For women eligible for both cancer screens, $64 \%$ indicated positive attitudes toward home-based colorectal and cervical cancer screening. While the age-appropriate-cancer-screen

Table 2. Frequency of Attitudes Toward Home-Based Screening

\begin{tabular}{lccc}
\hline & $\begin{array}{c}\text { Urine cervical } \\
\text { cancer screening, } \\
\mathbf{N}=\mathbf{7 6}\end{array}$ & $\begin{array}{c}\text { Vaginal cervical } \\
\text { cancer screening, } \\
\mathbf{N = 7 6}\end{array}$ & $\begin{array}{c}\text { Fecal colorectal } \\
\text { cancer screening, } \\
\mathbf{N = 1 3 2}\end{array}$ \\
\cline { 2 - 4 } Attitude & $\mathbf{n}(\%)$ & $\mathbf{n}(\%)$ & $\mathbf{n}(\%)$ \\
\hline I would rather not get screened at all & $8(10.5 \%)$ & $8(10.5 \%)$ & $9(6.8 \%)$ \\
$\begin{array}{l}\text { I would prefer to delay screening until I could } \\
\quad \text { return to the office }\end{array}$ & $8(10.5 \%)$ & $13(17.1 \%)$ & $21(15.9 \%)$ \\
$\begin{array}{l}\text { Maybe } \\
\text { Yes, but only if the physician was not offering } \\
\quad \text { in-office exams }\end{array}$ & $11(14.5 \%)$ & $10(13.2 \%)$ & $23(17.4 \%)$ \\
Yes & $25(32.9 \%)$ & $25(32.9 \%)$ & $35(26.5 \%)$ \\
\hdashline$\quad 24(31.6 \%)$ & $20(26.3 \%)$ & $44(33.3 \%)$ \\
\hline Comparison of positive vs negative attitude & $P<0.001$ & $P<0.001$ & $P<0.001$ \\
\hline
\end{tabular}


Table 3. Predictors of Home-Based Cancer Screening

\begin{tabular}{|c|c|c|c|c|c|c|}
\hline \multirow[b]{2}{*}{ Variable } & \multicolumn{2}{|c|}{$\begin{array}{l}\text { Urine cervical } \\
\text { cancer screening }\end{array}$} & \multicolumn{2}{|c|}{$\begin{array}{l}\text { Vaginal cervical } \\
\text { cancer screening }\end{array}$} & \multicolumn{2}{|c|}{$\begin{array}{l}\text { Fecal colorectal } \\
\text { cancer screening }\end{array}$} \\
\hline & OR & $95 \% \mathrm{Cl}$ & OR & $95 \% \mathrm{Cl}$ & OR & $95 \% \mathrm{Cl}$ \\
\hline \multicolumn{7}{|l|}{ Population group } \\
\hline Diabetic & 4.25 & $0.69,26.13$ & 1.80 & $0.43,7.53$ & 2.37 & $0.87,6.46$ \\
\hline Respiratory & 1.22 & $0.33,4.60$ & 1.20 & $0.34,4.25$ & 2.48 & $0.85,7.24$ \\
\hline Hospitalized & 1.00 & - & 1.00 & - & 1.00 & - \\
\hline Age & 0.95 & $0.89,1.01$ & 0.98 & $0.90,1.02$ & 1.00 & $0.97,1.03$ \\
\hline \multicolumn{7}{|l|}{ Race } \\
\hline White & 1.00 & - & 1.00 & - & 1.00 & - \\
\hline Black & 0.47 & $0.12,1.92$ & 0.89 & $0.23,3.39$ & 0.46 & $0.16,1.29$ \\
\hline Other & 0.24 & $0.04,1.37$ & 0.30 & $0.06,1.51$ & 0.71 & $0.17,3.04$ \\
\hline \multicolumn{7}{|l|}{ Gender } \\
\hline Female & - & - & - & - & 1.35 & $0.58,3.16$ \\
\hline Male & - & - & - & - & 1.00 & - \\
\hline \multicolumn{7}{|l|}{ Occupation } \\
\hline Employed & 1.00 & - & 1.00 & - & 1.00 & - \\
\hline Student & - & - & - & - & - & - \\
\hline Unemployed & - & - & - & - & - & - \\
\hline Retired/Disabled & 1.66 & $0.33,4.12$ & 0.89 & $0.27,2.92$ & 0.60 & $0.23,1.61$ \\
\hline \multicolumn{7}{|l|}{ Education } \\
\hline High school or less & 1.00 & - & 1.00 & - & 1.00 & - \\
\hline Some college & 1.05 & $0.20,5.60$ & 0.82 & $0.16,4.20$ & 2.25 & $0.60,8.48$ \\
\hline Completed college & 0.63 & $0.12,8.94$ & 0.38 & $0.07,1.89$ & 1.10 & $0.31,3.91$ \\
\hline Post college & 3.19 & $0.44,23.01$ & 1.88 & $0.31,11.52$ & 6.75 & $1.37,33.26$ \\
\hline \multicolumn{7}{|l|}{ Number in household } \\
\hline 1 or 2 & 1.89 & $0.59,6.07$ & 1.61 & $0.55,4.70$ & 0.56 & $0.23,1.34$ \\
\hline More than 2 & 1.00 & - & 1.00 & - & 1.00 & - \\
\hline \multicolumn{7}{|l|}{ Tobacco use } \\
\hline Ever/Current & 0.79 & $0.21,2.98$ & 0.74 & $0.23,2.39$ & 1.68 & $0.68,4.13$ \\
\hline Never & 1.00 & - & 1.00 & - & 1.00 & - \\
\hline \multicolumn{7}{|l|}{ Length of time with $\mathrm{PCP}$} \\
\hline Less than 3 years & 1.00 & - & 1.00 & - & 1.00 & - \\
\hline 3 years or more & 0.57 & $0.18,1.81$ & 0.54 & $0.18,1.59$ & 0.41 & $0.17,1.00$ \\
\hline \multicolumn{7}{|l|}{ Insurance } \\
\hline Private (employer or self-purchased) & 1.00 & - & 1.00 & - & 1.00 & - \\
\hline $\begin{array}{l}\text { Public (Medicaid, Medicare, Tribal, other } \\
\text { state-sponsored) }\end{array}$ & 0.91 & $0.28,2.95$ & 0.84 & $0.29,2.41$ & 1.33 & $0.56,3.18$ \\
\hline $\begin{array}{l}\text { Positive attitude toward home-based } \\
\text { colorectal cancer screening }\end{array}$ & 52.50 & $8.40,328.00$ & 25.44 & $4.70,137.77$ & - & - \\
\hline $\begin{array}{l}\text { Positive attitude toward home-based urine } \\
\text { cervical cancer screening after adjusting } \\
\text { for education }\end{array}$ & - & - & - & - & $48.72^{*}$ & $7.05,336.82$ \\
\hline $\begin{array}{l}\text { Positive attitude toward home-based vaginal } \\
\text { cervical cancer screening after adjusting } \\
\text { for education }\end{array}$ & - & - & - & - & $23.23^{*}$ & $3.80,141.84$ \\
\hline
\end{tabular}

*adjusted odds ratio.

OR, odds ratio; PCP, primary care physician. 
Table 4. Frequencies Limited to the Appropriate Age Ranges for Cancer Screenings

\begin{tabular}{|c|c|c|c|c|}
\hline \multirow[b]{3}{*}{ Screening test } & \multicolumn{2}{|c|}{$\begin{array}{c}\text { Recommended ages for } \\
\text { colorectal cancer } \\
\text { screening }\end{array}$} & \multirow{2}{*}{$\begin{array}{c}\text { Recommended } \\
\text { ages for primary } \\
\text { HPV screening } \\
\text { Women: } \\
25-65 \text { years } \\
\end{array}$} & \multirow{2}{*}{$\begin{array}{c}\text { Intersecting age } \\
\text { ranges for both } \\
\text { screenings } \\
\text { Women: } \\
45-65 \text { years } \\
\end{array}$} \\
\hline & $\begin{array}{c}\text { Men: } \\
\text { 45-75 years }\end{array}$ & $\begin{array}{c}\text { Women: } \\
45-75 \text { years }\end{array}$ & & \\
\hline & $\mathrm{N}=\mathbf{3 0}$ & $\mathrm{N}=43$ & $\mathrm{~N}=34$ & $\mathrm{~N}=\mathbf{2 5}$ \\
\hline \multicolumn{5}{|l|}{ Stool colorectal cancer testing, $n(\%)$} \\
\hline I would rather not get screened at all & $0(0 \%)$ & $1(2.3 \%)$ & - & $0(0 \%)$ \\
\hline $\begin{array}{l}\text { I would prefer to delay screening until I } \\
\text { could screen in the office }\end{array}$ & $9(30.0 \%)$ & $7(16.3 \%)$ & - & $3(12.0 \%)$ \\
\hline Maybe & $3(10.0 \%)$ & $9(20.9 \%)$ & - & $6(24.0 \%)$ \\
\hline $\begin{array}{l}\text { Yes, but only if the physician was not } \\
\text { offering in-office exams }\end{array}$ & $6(20.0 \%)$ & $11(25.6 \%)$ & - & $6(24.0 \%)$ \\
\hline Yes & $12(40.0 \%)$ & $15(34.9 \%)$ & - & $10(40.0 \%)$ \\
\hline \multicolumn{5}{|l|}{ Urine HPV testing, n (\%) } \\
\hline I would rather not get screened at all & - & - & $0(0 \%)$ & $0(0 \%)$ \\
\hline $\begin{array}{l}\text { I would prefer to delay screening until I } \\
\text { could screen in the office }\end{array}$ & - & - & $3(8.8 \%)$ & $3(12.0 \%)$ \\
\hline Maybe & - & - & $4(11.8 \%)$ & $4(16.0 \%)$ \\
\hline $\begin{array}{l}\text { Yes, but only if the physician was not } \\
\text { offering in-office exams }\end{array}$ & - & - & $12(35.3 \%)$ & $7(28.0 \%)$ \\
\hline Yes & - & - & $15(44.1 \%)$ & $11(44.0 \%)$ \\
\hline Vaginal HPV testing, $n(\%)$ & - & - & & \\
\hline I would rather not get screened at all & - & - & $1(2.9 \%)$ & $1(4.0 \%)$ \\
\hline $\begin{array}{l}\text { I would prefer to delay screening until I } \\
\text { could screen in the office }\end{array}$ & - & - & $3(8.8 \%)$ & $3(12.0 \%)$ \\
\hline Maybe & - & - & $5(14.7 \%)$ & $5(20.0 \%)$ \\
\hline $\begin{array}{l}\text { Yes, but only if the physician was not } \\
\text { offering in-office exams }\end{array}$ & - & - & $16(38.2 \%)$ & $7(28.0 \%)$ \\
\hline Yes & - & - & $12(35.3 \%)$ & $9(36.0 \%)$ \\
\hline
\end{tabular}

HPV, human papillomavirus.

sample sizes were small, the frequencies were similar to that of the entire study population, which was powered to see differences in acceptance.

\section{DISCUSSION}

This pilot work revealed that, in the first year of the COVID-19 pandemic, adults with health care needs generally had positive attitudes toward home-based cancer screenings. Despite expecting people with diabetes, who may be used to home glucose testing and monitoring diet/exercise, to have greater acceptance of home-based screening, the majority of respondents in each study cohort had a positive response to at-home cancer screening scenarios. To date, very little work has focused on both home-based colorectal and cervical cancer screenings. We find it appropriate to link these two at-home screens together, as for women, they could be efficiently accomplished with a single at-home bathroom experience.
Our study showed that traditional barriers to screening, ${ }^{11}$ such as less education, male gender, non-White race, and occupational status, did not affect the positive attitudes for at-home cancer screening. In addition, our data did not indicate that a long-term physician relationship affected attitudes toward home-based cancer screening, a factor previous shown to be important for adherence to other cancer screenings. ${ }^{12-14}$ Instead, we found that adults have a positive attitude toward home-based screening when given an option, even during an infectious pandemic with restrictive access to health care.

Our study does have limitations. While the response rate in each of the three patient groups was too small for generalizability, the overall data did appear to show that acceptability of home-based cancer screening was above the 2020 Centers for Disease Control and Preventionreported fecal occult blood test/fecal immunochemical 
test rates. $^{15}$ In addition, this was a cross-sectional study of hypothetical screening scenarios without full cancer screening education or input from respondents' primary care physicians. Lastly, the confidence intervals surrounding the odds ratios predicting home-based screening acceptance were very large, requiring a much larger future survey sample to confirm results.

While the COVID-19 pandemic has accelerated the use of video and phone visits to facilitate the delivery of health care, ${ }^{15,16}$ the movement to encourage homebased cancer screening has yet to increase. This pilot study found that adults have positive attitudes about home-based cancer screens, which could have multiple benefits for those who face barriers to office-based services (such as transportation, hours of accessibility, and poor past experiences with sexual abuse or other invasive medical exams). Home-based cancer screening may complement and expand the shift to the virtual delivery of health care, bringing tests to the homes of patients.

\section{Patient-Friendly Recap}

- As more health care shifts to virtual, at-home models, new approaches to cancer screening may prove beneficial.

- Authors surveyed 132 adults who had 1 of 3 limitations to receiving in-office cancer screening during the pandemic in order to gauge patients' attitudes toward completing home-based cervical or colorectal screens.

- A majority of female respondents reported that the at-home urine and vaginal HPV tests would be acceptable. Similarly, $60 \%$ of all respondents (men and women) approved of home-based colorectal cancer testing.

- Home-based cancer screening may improve compliance with recommended preventive care.

\section{Acknowledgments}

We thank Wendy Furst for her assistance with Qualtrics software and for organizing our work meetings.

\section{Author Contributions}

Study design: El Khoury, Haro, Alves, Sheinfeld Gorin, Jimbo, Sen, Harper. Data acquisition or analysis: El Khoury, O'Dwyer, Meixner, Albiac, Capizzano, Ramakrishnan, Salada, Harper. Manuscript drafting: El Khoury, Haro, Alves, Harper. Critical revision: all authors.

\section{Conflicts of Interest}

None.

\section{Funding Sources}

This work was supported by grants from the National Cancer Institute (P30CA046592) and the National Center for Advancing Translational Science (UL1TR001070).

\section{References}

1. Gorin SNS, Jimbo M, Heizelman R, Harmes KM, Harper DM. The future of cancer screening after COVID-19 may be at home. Cancer. 2021;127:498-503. CrossRef

2. Epic Health Research Network. Delayed cancer screenings. Published May 4, 2020; accessed November 20, 2020. https:// ehrn.org/articles/delays-in-preventive-cancer-screenings-duringcovid-19-pandemic/

3. Heath $\mathrm{S}$. How is coronavirus affecting chronic disease management care? PatientEngagementHIT. Published April 20, 2020; accessed November 20, 2020. https:// patientengagementhit.com/news/how-is-coronavirusaffecting-chronic-disease-management-care

4. De Biase S, Cook L, Skelton DA, Witham M, Ten Hove R. The COVID-19 rehabilitation pandemic. Age Ageing. 2020;49:696-700. CrossRef

5. Evidation.com. COVID-19 Pulse: Delivering regular insights on the pandemic from a $150,000+$ person connected cohort. Published March 18, 2020; last updated on April 15, 2020; accessed November 20, 2020. https://evidation.com/news/ covid-19-pulse-first-data-evidation/

6. Caleia AI, Pires C, Pereira JF, Pinto-Ribeiro F, Longatto-Filho A. Self-sampling as a plausible alternative to screen cervical cancer precursor lesions in a population with low adherence to screening: a systematic review. Acta Cytol. 2020;64:332-43. CrossRef

7. Sahasrabuddhe VV, Luhn P, Wentzensen N. Human papillomavirus and cervical cancer: biomarkers for improved prevention efforts. Future Microbiol. 2011;6:1083-98. CrossRef

8. U.S. Preventive Services Task Force. Colorectal cancer: screening. Last reviewed October 27, 2020; accessed November 20, 2020. https://uspreventiveservicestaskforce.org/uspstf/draftrecommendation/colorectal-cancer-screening3\#: : text=In $\% 20$ the $\% 20$ current $\% 20 \mathrm{draft} \% 20$ recommendation,years $\% 20(\mathrm{~B} \% 20$ grade $\% 20$ recommendation)

9. Wolf AMD, Fontham ETH, Church TR, et al. Colorectal cancer screening for average-risk adults: 2018 guideline update from the American Cancer Society. CA Cancer J Clin. 2018;68: 250-81. CrossRef

10. Fontham ETH, Wolf AMD, Church TR, et al. Cervical cancer screening for individuals at average risk: 2020 guideline update from the American Cancer Society. CA Cancer J Clin. 2020;70:321-46. CrossRef

11. Harper DM, Plegue M, Harmes KM, Jimbo M, SheinfeldGorin $\mathrm{S}$. Three large scale surveys highlight the complexity of cervical cancer under-screening among women 45-65 years of age in the United States. Prev Med. 2020;130:105880. CrossRef

12. Fox SA, Heritage J, Stockdale SE, Asch SM, Duan N, Reise SP. Cancer screening adherence: Does physician-patient communication matter? Patient Educ Couns. 2009;75:178-84. CrossRef

13. Lobchuk MM, Bapuji SB, McClement SE, et al. What is the role of family in promoting faecal occult blood test screening? Exploring physician, average-risk individual, and family perceptions. Cancer Epidemiol. 2012;36:e190-9. CrossRef 
14. Mainous AG 3rd, Baker R, Love MM, Gray DP, Gill JM. Continuity of care and trust in one's physician: evidence from primary care in the United States and the United Kingdom. Fam Med. 2001;33:22-7.

15. National Cancer Institute Cancer Trends Progress Report. Colorectal cancer screening. Accessed November 20, 2020. https://progressreport.cancer.gov/detection/colorectal cancer

16. Koonin LM, Hoots B, Tsang CA, et al. Trends in the use of telehealth during the emergence of the COVID-19 pandemic - United States, January-March 2020. MMWR Morb Mortal Wkly Rep. 2020;69:1595-9. CrossRef
17. Borfitz D. Long view on the role of telehealth in primary care. Diagnostics World. Published May 12, 2020; accessed November 20, 2020. https://www.diagnosticsworldnews.com/ news/2020/05/12/long-view-on-the-role-of-telehealth-inprimary-care

(C) 2021 Advocate Aurora Health, Inc. 